\title{
Nietzsche's Pluralism about consciousness
}

\author{
Mattia Riccardi (Bonn)
}

\{ This is the penultimate draft of a paper published in the BJHP (issue 24.1, 2016, DOI:10.1080/09608788.2015.1092945). Please only quote the published version.

\section{1) Introduction}

Talk of consciousness is notoriously ambiguous. There are two basic philosophical reactions to this fact. On the one hand, one could hold this ambiguity to be a superficial feature of our linguistic practice obscuring the deeper fact that all the situations we describe by appeal to "consciousness" and its cognates involve a unique, fundamental kind of consciousness. This would be to accept monism about consciousness. On the other hand, one could choose take our unstable way of talking as evidence that there is no unique, fundamental kind of consciousness. This would be pluralism about consciousness.

The aim of this paper is to show that Nietzsche's view of consciousness is best understood as a version of pluralism. Now, given that in our ordinary talk one important clue in favour of pluralism is the unstable pattern of use associated with "consciousness" and its cognates, one could expect that my proposal is also prompted by similar ambiguities on Nietzsche's part. However, and perhaps surprisingly, the occurrences of the term in his writingsreveal a relatively stable usage. What motivates my proposal is something different.

On the one hand, associated with Nietzsche's standard use of the term there is - at least to contemporary eyes — quite a peculiar notion of consciousness 
that, given the preeminent role it plays in his writings, I shall call the dominant notion. On the other hand, he elsewhere offers a characterization of typically conscious states like perceptions and sensations such that they cannot qualify as conscious in the sense of the dominant notion. This seems to suggest that he takes different types of consciousness to be involved in those states - types which do not coincide with that picked out by the dominant notion. Of course, all this needs substantial unpacking. That is what the remainder of my paper intends to offer.

Before I go on to this task, it shall be helpful to supply a brief overview of the existing literature. Though most interpreters do not take any explicit stance on this specific issue, a number of scholars seem to believe that Nietzsche adopts some version of consciousness monism. Simon (1984), Schlimgen (1999) and Abel (2001) — the most relevant contributions on this topic within German Nietzsche scholarship — converge on what Abel calls the "continuum model" (2001: 8), according to which mental disparities - those in consciousness included - across the animal realm manifest the varying degrees of complexity of a unique and universal kind of mindedness. Poellner (1995, ch. 5.2), Anderson (2002), Richardson (2004) and Doyle (2011) also seem to assume that for Nietzsche there is only one type of consciousness. To my knowledge, however, only Katsafanas (2005 and, in particular, 2015) explicitly defends this claim. For this reason, I shall discuss his position in more detail.

A minority of scholars have suggested a dualist reading according to which Nietzsche acknowledges the existence of two different kinds of consciousness. This is the case of Constâncio (2012) and Welshon (2014: ch 3.1, 75; ch. 5.1: 137-138), who both note that, though Nietzsche's interest is usually directed at the sophisticated kind of consciousness instantiated solely by human 
beings, he also recognizes a distinct, more basic and not exclusively human type of consciousness.

The argument put forward in this paper aims at substantiating the kind of anti-monist approach favoured by Constâncio and Welshon. However, the reading proposed here will diverge considerably from theirs, as I shall argue that Nietzsche is best understood as distinguishing between three different types of consciousness.

Of course, whether pluralism about consciousness is a philosophically attractive position in its own right is a quite different and very substantial question. At face value, monism might appear to be the most appealing option, as it allows reducing all the daunting variety of conscious phenomena to a unique, fundamental type of consciousness. On the contrary, pluralism seems to exclude any such unified account. This general issue runs very deep and cannot be properly addressed here. The most that can be undertaken on this occasion is to show that, if one were to accept the story Nietzsche provides about the dominant notion of consciousness, pluralism would then be the most sensible choice. This is a topic I shall come back to in the last section of the paper.

\section{2) Uncovering the dominant notion}

In this section, I shall focus on Nietzsche's dominant notion. ${ }^{1}$ In particular, I shall highlight six features of the kind of consciousness it picks out $-{ }^{\mathrm{D}}$ consciousness,

\footnotetext{
${ }^{1}$ Here, I take up some claims defended in ANONYMISED-c.
} 
from now on. All these features emerge, with variable straightforwardness, from what Nietzsche writes in aphorism 354 from Gay Science. It begins like this:

The problem of consciousness (or rather, of one's becoming conscious [des Sich-Bewusst-Werdens]) first confronts us when we begin to realize how much we can do without it; and now we are brought to this initial realization by physiology and natural history (Thiergeschichte) (which have thus required two hundred years to catch up with Leibniz's precocious suspicion). For we could think, feel, will, remember and also 'act' in every sense of the term, and yet none of all this would have to 'enter our consciousness' (as one says figuratively). All of life would be possible without, as it were, seeing itself in the mirror; and still today, the predominant part of our lives actually unfolds without this mirroring — of course also our thinking, feeling, and willing lives, insulting as it may sound to an older philosopher. To what end does consciousness exist at all when it is basically superfluous? (GS 354, translation changed)

One feature displayed by ${ }^{\mathrm{D}}$ consciousness is some sort of reflexivity [1]. First, this is clearly indicated by Nietzsche's description of ${ }^{\mathrm{D}}$ consciousness, at the very beginning of the aphorism, as “one's becoming conscious". (That some form of reflexivity is involved here appears even more explicit in the original German expression "Sich-Bewusst-Werden".) Second, it is suggested by Nietzsche's metaphorically depicting Dconsciousness as life's "seeing itself in the mirror".

A further feature is that it is specifically human [2], as implied by Nietzsche's reference to the — by his time — recent development of "physiology 
and natural history". In particular, his point seems to be that discoveries made in these disciplines started to show that ${ }^{\mathrm{D}}$ consciousness is such that animals ${ }^{2}$ can do well without possessing it. Indeed, according to Nietzsche also most of our (human) mental life and of our (human) behaviour does not depend on it, as "we could think, feel, will, remember and also 'act' in every sense of the term, and yet none of all this would have to "enter our consciousness"".

It requires much more work to uncover the third feature of ${ }^{\mathrm{D}}$ consciousness. The discoveries in "physiology and natural history" referred to in GS 354 are supposed to have developed a "precocious suspicion" originally occurred to Leibniz. As Nietzsche's concern is with the role consciousness plays in our mental life, most scholars interpret this as a reference to Leibniz' famous notion of petites perceptions. ${ }^{3}$ However natural this reading might be, I think it is, if not completely wrong, at least inaccurate and easily misleading.

To see why, consider that the mental states Nietzsche is primarily concerned with in GS 354 are not perceptual ones, but rather what philosophers nowadays call propositional attitudes (thoughts, emotions, desires and memories). Now, I think it is reasonable to doubt that the petites perceptions model, which is put forward specifically as an account of how perception works, can be usefully applied also to propositional states. Consider how Leibniz illustrates his notion:

I would prefer to distinguish between perception and being aware. For instance, a perception of light or colour of which we are aware is made up of many minute perceptions of which we are unaware; and a noise which we perceive but do not attend to is brought within reach of our awareness by a

\footnotetext{
2 Note that "natural history" reads "Thiergeschichte" in German.

${ }^{3}$ See Löwith (1967), Simon (1984) and Anderson (2002).
} 
tiny increase or addition. If the previous noise had no effect on the soul, this minute addition would have none either, nor would the total. (Leibniz 1765: IX §4)

Here, Leibniz claims that a given perception is composed of small perceptions of which we cannot per se become aware. What we can become aware of are rather bigger perceptions constituted by agglomerates of such small perceptions. Now, how are we to conceive of this model as applied to thoughts or desires? At least, it strikes me as somewhat strange to distinguish in an analogous fashion between, for instance, "small thoughts" we cannot be aware of and "big thoughts" of which alone we can become conscious.

My suspicion regarding Leibniz's own suspicion is confirmed by what Nietzsche writes in GS 357, just a few pages later. There, he again refers to Leibniz, namely to his "incomparable insight" according to which "consciousness is merely an accidens of representation and not its necessary and essential attribute; so that what we call consciousness constitutes only one state of our mental and psychic world [...] and by no means the whole of it" (GS 357, translation changed). Now, I think it is fair to assume that the "incomparable insight" mentioned in GS 357 is the view that also substantiates the "precocious suspicious" ascribed to Leibniz in GS 354.

To better spell this point, it is important to consider that the characterization of Leibniz's claim we find in GS 357 is borrowed almost wordto-word from Otto Liebmann's Analysis der Wirklichkeit, a book that Nietzsche read heavily (see Loukidelis 2006). The corresponding passage in Liebmann's work appears as part of his discussion of Leibniz's reply to Locke on the issue of 
innateness. In particular, Liebmann praises Leibniz's “psychological discovery” according to which "'to have representations' and 'to be oneself conscious of them' is by no means the same", for "there are in us many latent and unconscious representations" (Liebmann 1880: 212). More specifically, the Leibnizian notion he explicitly refers to in this context is that of "connaissance virtuelle" as opposed to "connaissance actuelle", which roughly corresponds to the contemporary distinction between "non-occurrent belief" and "occurrent belief". Importantly, this distinctionis also pertinent to what Nietzsche says in GS 354. As you might recall, there he argues that we could "think, feel, will, remember" without there being any need for the relevant attitudinal state to turn ${ }^{\mathrm{D}}$ conscious. Thus, states of this sort can either remain ${ }^{\mathrm{D}}$ unconscious or become ${ }^{\mathrm{D}}$ conscious. To this claim I shall refer to as Leibniz's Thesis.

Elsewhere I have argued that the Leibniz's Thesis endorsed by Nietzsche is best illuminated in terms of a higher-order thought (HOT) conception of consciousness. Here I shall not repeat the arguments in favor of this claim. I just want to record that one of Nietzsche's characterizations of ${ }^{\mathrm{D}}$ consciousness in GS 354 seems to support it. ${ }^{4}$ What I have in mind is Nietzsche's description of one being ${ }^{\mathrm{D}}$ conscious as being in a position 'to 'know' what distressed him, to 'know' how he felt, to 'know' what he thought" (GS 354). This suggests, at least to me, that for a certain mental state $\mathrm{M}$ to be ${ }^{\mathrm{D}}$ conscious it is required that $\mathrm{M}$ be the content of a higher-order thought to the effect that I am in M. For instance, to be conscious of my current thought "that $p$ " I need to "know" that I think that $p$, and to "know" that I think that $p$ is just to have the higher-order thought "I think" which is about my first-order mental state "that $p$ ". If we assume that this line of

\footnotetext{
${ }^{4}$ A HOT reading of Nietzsche's view of consciousness is also defended by Doyle (2011) and Katsafanas (2014).
} 
reasoning is correct, we can finally conclude that ${ }^{\mathrm{D}}$ consciousness works according to a HOT model [3].

The next two features emerge by what Nietzsche says about the relation between ${ }^{\mathrm{D}}$ consciousness and language. First, he puts forward the "conjecture that consciousness in general has developed only under the pressure of the need to communicate" (GS 354). As he goes on, ${ }^{\mathrm{D}}$ consciousness "is really just a net connecting one person with another-only in this capacity did it have to develop; the solitary and predatory person would not have needed it" (GS 354). Further in the same aphorism, he then argues that "man, like every living creature, is constantly thinking but does not know it" and that conscious thinking not only is "the smallest part of it", but also the only kind of thinking which "takes place in words, that is, in communication symbols" (GS 354). This picture suggests, first, that ${ }^{\mathrm{D}}$ consciousness is tied to the development of those specific communicative practices [4] that evolved in early human societies as a response to the threats and challenges posited by a hostile environment and, second, that ${ }^{\mathrm{D}}$ conscious thinking is intrinsically linguistic in a way in which the cognitive processes that remain Dunconscious are not. Here, the notion of "thinking" should be taken as a wide notion covering, at least, all attitudinal states. Therefore, his claim seems to be that all and only conscious mental contents are articulated propositionally [5].

I now turn to the last feature. As Nietzsche has it, "due to the nature of animal consciousness, the world of which we can become conscious is merely a surface- and sign-world, a world turned into generalities and thereby debased of its lowest common denominator", so that "all becoming conscious involves a vast and thorough corruption, falsification, superficialization, and generalization" (GS 354). The last feature of ${ }^{\mathrm{D}}$ consciousness is therefore that it involves some kind of 
profound falsification [6]. It is not easy to make sense of this claim. As the issue of falsification will play a key role in my argument in favour of a pluralist, I shall come back to it later in the paper. For now, let me just summarize the six features of the notion of consciousness Nietzsche deals with in GS 354.

If my argument, so far, is right, ${ }^{\mathrm{D}}$ consciousness

[1] is, in some sense, reflexive.

[2] is human-specific.

[3] is such that a mental state is ${ }^{D}$ conscious iff it is targeted by a higherorder thought.

[4] has evolved together with communicative and linguistic practices.

[5] is such that all and only ${ }^{\mathrm{D}}$ conscious states have propositionally articulated content.

[6] involves some kind of falsification.

We are now in a position to answer the question about the nature of

D consciousness. What type of consciousness might fit the description provided by features [1] to [6]? Let us start by excluding some important candidates. First, consider so-called phenomenal consciousness: that peculiar qualitative character of pains or colour sensations which is taken to provide the most basic notion of consciousness. Clearly, this cannot be the notion Nietzsche is concerned with, as it does not satisfy most of the features emerging from GS 354. It is usually believed that sentience is a sufficient condition for phenomenal consciousness. Therefore, it is taken to be widespread in the animal realm (against [2]) and, consequently, to not require any communicative nor linguistic ability (against [4] and [5]). Second, consider the kind of awareness which is typical of perceptual experience. Again, it seems obvious that many animals see and smells things in 
their environment (against [2]) and that such perceptual encounters do not depend on the possession of linguistic capacities (against [4] and [5]). So which kind of consciousness might ${ }^{\mathrm{D}}$ consciousness be?

The proposal I want to make here is that what Nietzsche is talking about is a certain kind of self-consciousness — ${ }^{\mathrm{S}}$ consciousness, as I shall abbreviate it. $^{5}$ Usually, ${ }^{\mathrm{S}}$ consciousness is predicated of creatures, not of the mental states they instantiate. However, since Nietzsche applies the dominant notion of consciousness also to states, I should explain what it means to say of a mental state that it is ${ }^{\mathrm{S}}$ conscious. By this I just mean that its becoming conscious involves its being ascribed to a self.

Now, ${ }^{\mathrm{S}}$ consciousness clearly satisfies [1] and can be plausibly said to be in some sense linguistic and thus also satisfies [4] and [5]. If this is true, a fortiori it also satisfies [2]. But why think it is plausible that ${ }^{\mathrm{S}}$ consciousness is linguistic? A good answer might be that it requires some kind of self-referential capacity which, in turn, requires one to master the first-person pronoun. Should we then conclude that animals lack ${ }^{\mathrm{S}}$ consciousness? Well, given the notion of ${ }^{\mathrm{S}}$ consciousness we are dealing with, I think we actually should. To mitigate the chauvinistic impression this answer might raise, one could perhaps add that animals lack what we might

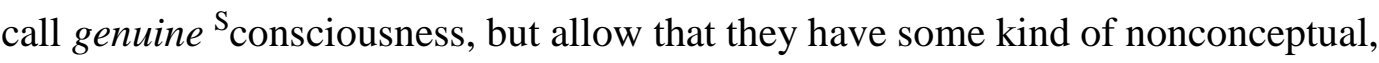
bodily self-awareness.

What about [3]? Usually, HOT models construe the higher-order thought which makes the targeted mental state $\mathrm{M}$ conscious as involving a reference to the subject. As David Rosenthal — the most prominent proponent of the HOT theory

\footnotetext{
${ }^{5}$ For a similar proposal see Welshon $(2014$, ch. 5), who argues that Nietzsche's notion is that of "reflective consciousness". Richardson, too, sometimes refers to the kind of consciousness Nietzsche deals with in GS 354 as "self-consciousness" (see, for instance, his 2004: 77, 90, 93, 160).
} 
nowadays - notes, a higher-order thought is a first-person thought and, as such, refers to the self in the essentially indexical way which is typical of the firstperson pronoun (see his 2005: 347-49). Therefore, if the higher-order thoughts appealed to by HOT-theorists involve a reference to the self as the one who is in the targeted state M, it seems at least plausible to hold that this feature is reflected in the way in which $\mathrm{M}$ becomes conscious. In short, it seems at least plausible to hold that $\mathrm{M}$ is ${ }^{\mathrm{S}}$ conscious in the sense clarified above.

We are left with [6]. If I am right in identifying Nietzsche's target notion, he maintains that ${ }^{\mathrm{S}}$ consciousness involves some kind of profound falsification. How are we to make sense of this claim? On this occasion, I cannot provide a fullfledged treatment of what Nietzsche has in mind. ${ }^{6}$ The key idea is that the social nature of ${ }^{\mathrm{S}}$ consciousness is such that it does not provide us with any access to our genuine self. Quite to the contrary, "each of us, even with the best will in the world to understand ourselves as individually as possible, to 'know ourselves', will always bring to consciousness precisely that in ourselves which is 'nonindividual' (GS 354). In support of this view, Nietzsche points to the intrinsically linguistic nature of ${ }^{\mathrm{S}}$ consciousness. In particular, he argues that language provides each of us with a certain set of mental terms and that such a socially-acquired psychological vocabulary governs the way in which we conceptualize our own mental states. Thus conceptualized is also how one's inner states become $\mathrm{S}_{\text {conscious, for the emergence of }} \mathrm{S}$ consciousness is tied to the communicative practice through which one acquires the relevant psychological vocabulary. But why think that all this involves, as Nietzsche maintains, "a thorough corruption, falsification, superficialization, and generalization"? 
Again, I can just give a very sketchy rendering of Nietzsche's complicated story. Very briefly, he thinks that the falsification in question is due to the very linguistic nature of ${ }^{\mathrm{S}}$ consciousness. First, the mental vocabulary we employ to conceptualize our inner states is typically utterly poor and inadequate to capture the richness of our mental life. As Nietzsche notes, "words really exist only for superlative degrees" or "extreme states". On reflection, "even the most moderate conscious pleasure or displeasure, while eating food or hearing a note, is perhaps, rightly understood, an extreme outburst" (D 115). The idea, therefore, is that we have no way to pick out by far the greatest part of the processes and states occurring in ourselves and, consequently, we just fail to ${ }^{\mathrm{S}}$ consciously attend to them. Second, Nietzsche thinks that the propositional structure of ${ }^{\mathrm{S}}$ conscious firstperson attitudes is responsible for a range of misunderstandings about the real nature of our inner life. For instance, the fact that the first-person pronoun is part of their content is the source of the — to Nietzsche's eyes wrong — belief that there is something — a soul, a subject—which is picked out by the word "I" and which is the bearer of one's attitudes. ${ }^{7}$

Let me briefly take stock. In this section, I have argued for two main theses. First, and most relevantly, the notion of consciousness Nietzsche is usually concerned with — what I called the dominant notion — is, in fact, that of selfconsciousness. Second, self-consciousness involves a profound falsification in virtue of its being essentially linguistic.

Is this all that Nietzsche has to tell us about consciousness? 


\section{3) Perceptual states}

Perception is usually taken to constitute a paradigmatic kind of conscious state. Typically, this intuitive view is also reflected in the philosophical debates on the nature of consciousness. Indeed, contemporary philosophers generally consider the case of perceptual experience — in particular, of visual experience - to provide a privileged arena in which to test the merits and drawbacks of a certain theory of consciousness. For this reason, I believe it is important to look at what Nietzsche says about perception - in particular, to the characterization offered by aphorism 192 from Beyond Good and Evil.

Just as little as today's reader takes in all the individual words (or especially syllables) on a page (he catches maybe five out of twenty words and 'guesses' what these five arbitrary words might possibly mean) — just as little do we see a tree precisely and completely, with respect to leaves, branches, colors and shape. We find it so much easier to imagine (phantasieren) an approximate tree instead ... . (BGE 192)

In my analysis, I shall focus on the example of one's perceiving a tree. Let us note, first, that such a perceptual state does not need to be ${ }^{\mathrm{S}}$ conscious, as, for all that Nietzsche says of it, it can occur even if some of the features of

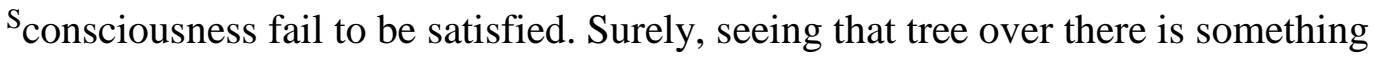
that many animals can do [2]. A fortiori, it does not depend on linguistic capacities [4], nor the resulting state needs to have propositional content [5]. 
Of course, one could object that this reasoning simply assumes that human and animal perception is exactly analogous. This, however, is a point open to substantial philosophical debate. For instance, some conceptualists (see, most notably, McDowell 1996) argue that human perceptual experience is shaped by our specific, language-dependent conceptual capacities and therefore differs essentially from that of other animals. In light of this, one could argue, it is simply question begging to assume that Nietzsche sees here no relevant divide between humans and other animals. This is an important point I shall come back to in due course. For now, let me just register that Nietzsche's description of the tree case does not make any explicit reference to language-dependent conceptual capacities.

Let us now turn to the other features of ${ }^{\mathrm{S}}$ consciousness. I think it is plausible to hold that a perceptual state, in order to be conscious, does not demand any kind of reflexivity [1] nor that it be in some way targeted by a higher-order thought [4]. But even if we leave these last two properties aside, it is clear that perceptual states do not satisfy at least three of the features of ${ }^{S}$ consciousness. Thus, it seems that the kind of consciousness involved in perceptual states is different from ${ }^{\mathrm{S}}$ consciousness. This second kind I shall call perceptual consciousness_- ${ }^{\mathrm{P}}$ consciousness, for short.

Interestingly, it seems that only one feature of ${ }^{\mathrm{S}}$ consciousness is also shared by ${ }^{\mathrm{P}}$ consciousness, namely, their involving some kind of falsification [6]. This is suggested, again, by Nietzsche's characterization of our visual experience of a tree. For, as he says, instead of seeing the tree "precisely and completely", we usually "imagine (phantasiren) an approximate tree". In general, as Nietzsche writes in the same aphorism, 
our senses learn late and never fully learn to be refined, trusty, careful organs of knowledge. Given some stimulus, our eyes find it more convenient to reproduce an image (Bild) that they have often produced before than to register what is different and new about an impression: the latter requires more strength, more 'morality'... . (BGE 192)

For the present purpose, two features of Nietzsche's characterization of the tree case prove particularly relevant. First, he argues that we do not usually attend to the actual properties of the perceived object. Rather, in perceptual experience the given object is represented as a token — that particular tree —of a general typethe type tree. To Nietzsche's eyes, this does not only mean that perception lacks the accuracy we usually assume it to have, but also that it positively falsifies "the given”. Second, BGE 192 explicitly construes the representational job of perception as depending on the reactivation of a stored mental image or picture. This point is relevant because it clearly indicates that Nietzsche treats perception as imagistic or pictorial, rather than propositional. Hence, there is no reason to suppose that Nietzsche endorses something akin to McDowell's conceptualist view to the effect that the content of human perception is shaped by the kind of linguistic capacities required for ${ }^{\mathrm{S}}$ consciousness. If this is so, there is also no reason to suppose he sees any essential difference between animal and human perception.

To summarize, Nietzsche takes ${ }^{\mathrm{S}}$ conscious and ${ }^{\mathrm{P}}$ conscious states to differ in terms of content: whereas the former have propositional content, the latter have pictorial content. Nonetheless, he also thinks that both kinds of content involve 
falsification. The underlying idea seems thus that falsification is ultimately due to generalization and that generalization is a mode of representation that pictorial as well as propositional content can realize. ${ }^{8}$

Against this entire line of thought, one could of course argue that S consciousness is the only type of consciousness there is and conclude that nonpropositional perceptual states are simply not conscious. Katsafanas (2005) ascribes a similar view to Nietzsche. More recently (see his 2015), he has further substantiated this reading by arguing that Nietzsche follows Schopenhauer's denial that animals possess any kind of consciousness whatsoever. As it is common knowledge that Nietzsche's debts to Schopenhauer are vast and deep, ${ }^{9}$ Katsafanas' case deserves careful examination.

To my eyes, the argument faces two major problems. First, the allegedly Schopenhauerian claim that animals lack consciousness seems utterly wrong. ${ }^{10}$ Thus, even if it were to turn out that Nietzsche in fact endorsed this implausible view, the question would remain as to why he so blindly followed Schopenhauer on that score. Second, and most importantly, Schopenhauer does not seem at all to deny that animals possess consciousness. To vindicate this claim, I shall briefly consider an illustrative sample of passages from his main work.

\footnotetext{
${ }^{8}$ I think it can be shown that Nietzsche takes propositional and pictorial content to share such a generalizing mode of representation for their being both conceptual. Of course, it is plain that propositional content is conceptual. The case of pictorial content is highly controversial, though. Nonetheless, given that Nietzsche defines concepts as "more or less determinate pictorial signs (Bildzeichen) for sensations that occur together and recur frequently" (BGE 268), it seems that he allows for the images he believes to be involved in perceptual states to count as conceptual. For a detailed argument, see Riccardi (2013). For disagreement, see Katsafanas (2005, 2015) and Constâncio (2011). 9 This is undoubtedly true for the specific issue of consciousness. For instance, Schopenhauer's description of human consciousness as involving "reflection" and as being a sort of "mirroring (Wiederschein)" is strikingly similar to the one offered in GS 354 (see WWR I § 8:36, translation changed). For more on this, see Constâncio (2011).

${ }^{10}$ Katsafanas (2015) stresses that, on his reading of Schopenhauer, the claim that animals lack consciousness does not entail that they have no mental life. This qualification, however, is hardly of any help, for the view still entails the quite bizarre claim that the pain felt by a gazelle caught in a lion's jaws is unconscious.
} 
Schopenhauer claims, "in man alone of all the inhabitants of the earth ... an entirely new consciousness has arisen" (WWR I $\S 8: 36$ ), namely, reflective consciousness. That the human one is an "entirely new" kind of consciousness, however, seems to indicate that different forms of consciousness, presumably in the animal realm, already pre-existed its emergence. This is precisely what Schopenhauer explicitly affirms in several other passages. The "consciousness of animals", he argues, can be figured out by "taking away certain properties of our own" (WWR II 5: 59). More precisely, the main feature we should subtract from human consciousness is its dependence on language-dependent, "abstract representations", i.e. "concepts" (ibid.). What remains left, thus, are states of mind lacking conceptual content, which Schopenhauer identifies with feelings (Gefühle). As he stresses, it is hard to define what a feeling is, for "the immeasurably wide sphere of this concept includes the most heterogeneous things" (WWR I § 11: 51). The only common factor seems just to be their negative feature of lacking any conceptual content. However, and crucially for our discussion, a feeling is said to be a "modification of consciousness" (52). Therefore, pace Katsafanas, Schopenhauer allows for conscious states-feelings but also sensations - that, in virtue of their being non-conceptual, animals can also undergo. Thus, if it is right in claiming that Nietzsche followed here Schopenhauer, what we should conclude is that he allowed for a kind of consciousness different from reflective consciousness and widespread in the animal realm. ${ }^{11}$

To conclude, we should read Nietzsche as holding that perceptual states are conscious in a way that differs from the way in which propositionally 
articulated states are conscious. In other words, ${ }^{\mathrm{P}}$ consciousness is different in kind from ${ }^{\mathrm{S}}$ consciousness.

\section{4) Sensations}

In the preceding sections, I have argued that Nietzsche is best read as admitting two different kinds of consciousness: ${ }^{\mathrm{S}}$ consciousness and ${ }^{\mathrm{P}}$ consciousness. At this point, one might reasonably expect that what he says about these two kinds of consciousness exhaust what he says on consciousness tout court. I believe, however, that this is not the case. Nonetheless, it will take us a bit to appreciate why. Let me start again by focusing on a passage, this time from Twilight of the Idols:

With the greatest respect, I will make an exception for the name of Heraclitus. When all the other philosophical folk threw out the testimony of the senses because it showed multiplicity and change, Heraclitus threw it out because it made things look permanent and unified. Heraclitus did not do justice to the senses either. The senses do not lie the way the Eleatics thought they did, or the way Heraclitus thought they did,- - they do not lie at all. What we do with the testimony of the senses, that is where the lies begin, like the lie of unity, the lie of objectification, of substance, of permanence... 'Reason' makes us falsify the testimony of the senses. (TI, 'Reason in Philosophy' 2) 
In her seminal (1990) work, Maudemarie Clark drew the attention of Nietzsche's scholars to this passage. The reason it has relevance is that it seems to bring some new elements to his epistemology. In particular, Clark convincingly shows that, whereas the earlier Nietzsche holds the senses to-in some sense-falsify reality, he now affirms that "they do not lie at all". The conclusion she recommends is that we should read the very late Nietzsche as rejecting the core epistemological view he defended in his previous works and, at the same time, as embracing a version of empirical realism. On this occasion, I shall not attempt to discuss the epistemological consequences carried by the characterization of the senses he provided in TI - to have a handy label, I shall call this view Sensualism. ${ }^{12}$ Rather, I shall try to work out a point implicit in Nietzsche's late Sensualism that is also germane to our present concern.

Clark's observation about the novelty brought in by Sensualism offers us an important lead. As we saw, in BGE 192 Nietzsche says that the "our senses learn late and never fully learn to be refined, trusty, careful organs of knowledge". Prima facie, this description seems to be in tension with the later claim to the effect that the senses "do not lie at all". One way of resolving the tension would be to hold that Nietzsche simply changed his mind. However, I do not think that such a move is needed. Rather, Sensualism's crucial thesis can be read as expressing the Kantian view that "it is correctly said that the senses do not err; yet not because they always judge correctly, but because they do not judge at all” (Kant 1781/1787: 384, A293/B350). Here, what is meant is that the deliverances of the senses - impression, sensations — cannot falsely represent because they do not represent at all: they do not bear any semantically loaded content. Alone full-

\footnotetext{
${ }^{12}$ For a detailed discussion of Nietzsche's Sensualism, see ANONYMISED-a.
} 
fledged perceptual experience, as we saw, (pictorially) represents objects as instances of general kinds and, consequently, raises the question about its way of representing being true or false - or, at least, accurate or inaccurate. It seems therefore coherent to state (i) that the primitive deliverances of the sensesimpressions, sensations - involve no kind of falsification and, at the same time, (ii) that some kind of falsification is involved in full-fledged perceptions.

This reading is supported by Nietzsche's claim that the "lies begin" with what "we do with the testimony of the senses", i.e., with "reason". The idea here seems to be that falsification is due to whatever cognitive operations are brought to bear on the primitive deliverances of the senses. Unpublished notes from the period in which Nietzsche was working on TI suggest that he conceived of such primitive deliverances as forming a "chaos" of sensations or impressions. ${ }^{13}$ As he writes, such a "chaos" is promptly "logified (logisirt)" (9[106] 1887, KSA 12:395), by which Nietzsche means - I submit — the kind of processing issuing in perceptual states having pictorial content.

What do all this bear on the question about the different notions of consciousness one can track in Nietzsche's writing? Recall that, though the content of ${ }^{\mathrm{P}}$ conscious states differs from that of ${ }^{\mathrm{S}}$ conscious states - the content is pictorial in the former case and propositional in the latter one-, they both falsify. In TI, however, Nietzsche claims that certain deliverances of the senses "do not lie at all”, i.e., involve no falsification whatsoever. As we saw, the kind of deliverances he seems to have in mind is the primitive "chaos" of raw sensations or impressions. Therefore, if we were to think that such sensations or impressions

\footnotetext{
${ }^{13}$ See Nietzsche's Nachlass from Fall 1887, where he talks of "Vielerlei der Sensationen" (9[89], KSA 12:382), "Sensationen-Wirrwarr" (9[91], KSA 12:383), "Chaos des Sinneneindrucks" and "SensationenChaos" (both 9[106], KSA 12:397 and 398).
} 
are in some sense conscious, we should conclude that the relevant kind of consciousness, as it does not involve any falsification whatsoever, differs from ${ }^{\mathrm{P}}$ consciousness and ${ }^{\mathrm{S}}$ consciousness.

Of course, this conditional holds only if its premise is granted. Typically, sensations and impressions are construed as conscious - indeed, they constitute the class of paradigmatic cases philosophers usually appeal to in order to illustrate what their idiom of phenomenal, or qualitative, consciousness is supposed to mean. According to a widespread view, it is entailed by the very notion of a sensation of colour that it be felt or sensed. That is, it is taken that sensations are necessarily conscious, i.e. phenomenally or qualitatively, conscious. Thus, if we accept the conditional, we should conclude that qualitative consciousness-

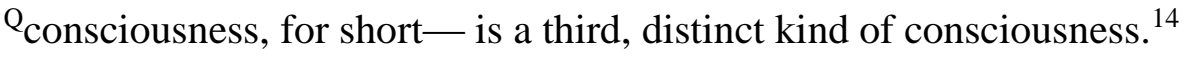

Several worries might be voiced against this reading. First, one might object that the premise of the conditional I endorse should be rejected as it anachronistically foists on Nietzsche a notion - that of phenomenal consciousness - which was unavailable to him. ${ }^{15}$ I am willing to recognize that the contemporary notion of phenomenal consciousness owes some of its traits to the debates on the nature of consciousness we have been witnessing over the past few decades. Nonetheless, I would like to argue that the idea of consciousness as fundamentally qualitative which constitutes the very core of that notion was already familiar to philosophers in the second half of the $19^{\text {th }}$ century. Moreover, the same kinds of states we nowadays classify under the rubric "phenomenal", i.e.

\footnotetext{
15 The anachronism problem does not arise with regard to the notions of ${ }^{\mathrm{P}}$ consciousness and $\mathrm{s}$ consciousness considered in the previous sections. In general, they are hardly in vogue in contemporary philosophy of mind. More importantly, ${ }^{\mathrm{S}}$ consciousness corresponds to a notion traditionally associated with classical German (Kantian and post-Kantian) philosophy, whereas ${ }^{\mathrm{P}}$ consciousness is tailored to Nietzsche's sui generis treatment of perception.
} 
sensations and raw feelings, were taken to constitute the most paradigmatic illustration of this specifically qualitative kind of consciousness. To substantiate this claim, I shall briefly comment on Schopenhauer's position and then consider two particularly representative historical examples from Nietzsche's own time.

As we saw in the preceding section, Schopenhauer considers feelings and sensations to constitute a class of strikingly heterogeneous conscious states marked by their lack of conceptual content. This picture seems to indicate that feelings and sensations can be typed only by appeal to their sensuous, essentially qualitative character. This suggests that Nietzsche should have been familiar with the idea that such states are conscious in a fundamentally qualitative way.

A brief look at two illustrative cases from the second half of the $19^{\text {th }}$ century will lend further support to this picture. The first one is Emile du BoisReymond's characterization of consciousness in his famous and, at the time, widely discussed essay entitled "The limits of our knowledge of nature (Über die Grenzen des Naturerkennens)". One of the epistemic limits the essay aims to vividly expose concerns our knowledge of the nature of consciousness. To this aim, du Bois-Reymond puts forward an apriori argument designed to establish that consciousness cannot be reduced to physical events and properties and which anticipates Frank Jackson's more recent “knowledge argument” (see Jackson 1982). As in case of contemporary anti-reductionist arguments, du Bois-Reymond assumes that the relevant "explanatory gap" is opened up by the "sensation of the senses (Sinnesempfindung)", which he characterizes as "consciousness at its first level" (1882:27). As he argues, "[w]ith the first impulse to contentment and pain the most simple being felt at the beginning of animal life on earth, or with the first perception of a quality, that unsurmountable gap is set up" (27-28). 
The second example is provided by Hermann von Helmholtz's theory of perception. This case is especially pertinent, not only because Helmholtz's view was extremely influential at the time, but also because we know that Nietzsche was familiar and, at least in part, sympathetic with it. ${ }^{16}$ According to Helmholtz, perceptions result from inferential processes operating on "phenomenally characterized sensations", as Gary Hatfield puts it (2002:132). Therefore, the basic posita of his theory are conceived of as essentially qualitative.

A second source of worry for the interpretation defended here stems from passages where Nietzsche seems to treat phenomenal states as involving cognitive capacities which go quite beyond mere sentience. Such passages not only threaten my characterization of such states as, in some sense, primitive deliverances, but also seems to undermine the need for a specific notion of ${ }^{Q_{\text {consciousness. So let }}}$ us take a look at those passages.

The first one is particularly pressing, as it is part of the same aphorism 354 where, I argued, Nietzsche puts forward his notion of ${ }^{S}$ consciousness. There we read that "the becoming conscious of one's own sense impressions (Sinneseindrücke), the power to be able to fix them and as it were to place them outside of oneself, as increased in proportion to the need to convey them to others by means of signs" (GS 354). The difficulty raised by this passage consists in that Nietzsche is talking of "sense impressions" as S conscious. Why should we then appeal to a further notion of consciousness in order to make sense of states of that kind?

Nietzsche claims that "sense impressions" turn conscious under the pressure of communication. There should be therefore no doubt that the notion of

\footnotetext{
${ }^{16}$ For the most detailed treatment of Nietzsche's debts to Helmholtz's sense physiology, see Reuter (2008).
} 
consciousness he is referring to is that of ${ }^{\mathrm{S}}$ consciousness. What does it mean, however, that the becoming conscious of sense impressions enabled one to "fixed them and as it were to place them outside of oneself'? Arguably, the ability Nietzsche has in mind depends on the essentially linguistic and communicative nature of ${ }^{\mathrm{S}}$ consciousness. More precisely, the perceptual vocabulary one acquires through social intercourse allows one, first, to "fix" one's fleeting sense impressions and, second, to report and hence communicate the content of such states. These capacities, however, are not incompatible with those states being Qconscious. Quite on the contrary, one's capacity to refer to and report one's sensations seems to require that they are already conscious in the phenomenal sense.

A different kind of challenge is raised by a claim made at the end of aphorism 127 from GS, according to which "that a violent stimulus is felt (empfunden) as pleasure or pain is a matter of the interpreting intellect, which, to be sure, generally works without our being conscious of it; and one and the same stimulus can be interpreted as pleasure or pain" (GS 127, translation changed). Here, Nietzsche affirms that feeling pain presupposes the interpretive work of the intellect and, consequently, is not a matter of immediate deliverance. Since pain counts as a paradigmatic example of ${ }^{{ }}$conscious state, it seems plausible to extend the claim to all states of that kind. We therefore end up with a view which clearly contradicts the thesis I have previously associated with Nietzsche's late Sensualism to the effect that ${ }^{\mathrm{Q}}$ conscious states like sensations and impressions are such primitive deliverances of the senses.

My strategy to deal with this is to argue that GS 127 defends a position Nietzsche came to abandon once he embraced Sensualism. This is manifest in the 
fact that the position in question includes the claim that the most basic deliverances of the senses already involve falsification in virtue of their being intellectual. This, however, is precisely the view Nietzsche rejects in TI by holding, quite to the contrary, that senses "do not lie at all".

The claim that states like pains or sensations are intellectual is somewhat opaque. Another aphorism from GS helps us to better understand what Nietzsche has in mind. There, he writes that "[t]hrough immense periods of time, the intellect produced nothing but errors" (GS 110), notable exemplars of which are beliefs such "that there are enduring things; that there are identical things; that there are things, kinds of material, bodies; that a thing is what it appears to be; that our will is free" (GS 110). Importantly, Nietzsche argues that many of those “erroneous articles of faith" turned out to enhance our ancestors' fitness and, consequently, became integrated into the most basic workings of our organism: "all its higher functions, the perceptions of the senses and generally every kind of sensation (jede Art von Empfindung überhaupt), worked with those basic errors that had been incorporated since time immemorial" (GS 110, my emphasis).

The relevant point for our discussion is that not only perceptions, but also sensations of any kind are considered to depend on the intellect's errors. This means, to put it in different terms, that no possible deliverance of the senses can be said to be free from falsification. This view, however, is precisely the one Nietzsche denies in TI, where he argues (i) that, at least at some basic level, the senses "do not lie at all" and (ii) that falsification starts where reason's false assumptions - like those of "unity", "objectification", "substance” or "permanence"- intervene on "the testimony of the senses". Remarkably, reason's sins quite accurately mirror those attributed to the intellect in GS 110. What 
Nietzsche changed his mind about is, rather, the reach of such cognitive operations. Whereas he previously held that they also penetrate the most basic sensory states, in TI he comes to endorse the view that such states - sensations and impressions - are immune to reason's "lies".

To conclude, I think there is no reason to believe that Nietzsche departs from tradition in conceiving of sensations and impressions as conscious states. If this is true, it follows that he takes such states to be conscious in a way which differs from that in which perceptions and propositional attitudes are conscious, as it does not involve any falsification whatsoever. This third kind of consciousness which is proprietary of sensations and impressions is qualitative consciousness$\mathrm{Q}_{\text {consciousness. }}$

\section{5) Concluding remarks}

One might ask whether the fact that we can track different notions of consciousness in Nietzsche's work suffices to substantiate attribution of pluralism. Perhaps, there is reasons to think that Nietzsche held that some notion is more fundamental than the others and, consequently, that some reductive strategy might be possible. For a range of reasons, this point is very hard to address. First, and though commitment to the notions of ${ }^{\mathrm{P}}$ consciousness and ${ }^{\mathrm{Q}}$ consciousness seems entailed by his treatment of perceptions and sensations, he does not explicitly theorize about such notions. It is therefore very difficult to find substantive clues on this specific issue. Second, it seems fair to say that, in general, Nietzsche was not at all interested in the metaphysical and epistemological questions usually 
associated with the problem of consciousness. Nonetheless, it is surely interesting, given the characterizations he offers of ${ }^{\mathrm{Q}_{\text {conscious, }}}{ }^{\mathrm{P}}$ conscious and ${ }^{\mathrm{S}}$ conscious states, to speculate about the relation between these three distinct notions. My view is that, given the picture emerging from Nietzsche's writings,

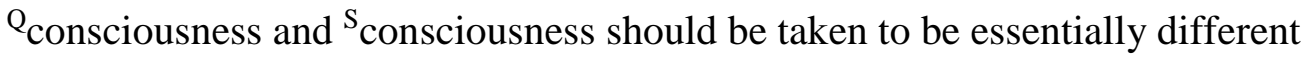
phenomena. On the one hand, ${ }^{\mathrm{S}}$ consciousness amounts to a cluster of merely cognitive capacities which are intimately related to communicative, linguistic and social practices. Thus, it seems plausible to think that a Chalmersian zombie-a physical and functional duplicate of yourself, but lacking ${ }^{\mathrm{Q}}$ consciousness altogether-might nonetheless be ${ }^{\mathrm{S}}$ conscious in Nietzsche's sense. On the other hand, ${ }^{\mathrm{Q}}$ consciousness is a basic phenomenon appearing together with sentience. As he writes in an unpublished note"Qualities are our unclimbable barriers; we cannot help sense mere quantitative differences as something fundamentally different from quantity, namely as qualities that cannot be further reduced one to another (1886 6[14], KSA 12:238)".This suggests that ${ }^{Q}$ consciousness constitutes the most fundamental way in which living beings react to the world external to them.

The status of ${ }^{\mathrm{P}}$ consciousness is more controversial. Perceptual states are in some sense hybrid: in virtue of their involving sensory qualities as well as pictorial content, they are both phenomenal and representational. . Accordingly, one could argue that perceptual states can be explained as a mixture of: (phenomenal) ${ }^{\mathrm{Q}}$ consciousness and (representational) ${ }^{\mathrm{S}}$ consciousness. Were we to ascribe this view to Nietzsche, he would then count as a consciousness dualist. ${ }^{17}$ However, I am not sure about this solution, as he seems to see a clear difference

\footnotetext{
${ }^{17}$ A dualism of this sort seems to be the one suggested by Constâncio (2012).
} 
between the kind of representational content of ${ }^{\mathrm{P}}$ conscious states, which is pictorial, and that of ${ }^{\mathrm{S}}$ conscious states, which is propositional. Thus, I think he holds ${ }^{\mathrm{P}}$ consciousness to be different in nature from ${ }^{\mathrm{S}}$ consciousness.

Perhaps, one could vindicate dualism by arguing that a ${ }^{\mathrm{P}}$ conscious state is just a ${ }^{Q}$ conscious state that also happens to have a certain kind of representational content. ${ }^{18}$ Again, I am not convinced by this proposal. Nietzsche's holding that perceptual states are necessarily falsifying in virtue of their being in some sense representational seems to suggest that they differ in nature from the primitive,

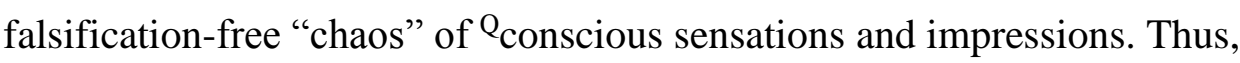
pluralism is still the horse I would bet on.

A more general point deserves also mention. For given that Nietzsche provides a HOT account of ${ }^{\mathrm{S}}$ consciousness — his dominant notion-, there are also good philosophical reasons for him not to endorse monism and to favor pluralism (or, at least, dualism) about consciousness. As Ned Block observes, a higher order theory of consciousness can be held as an immodest (or ambitious) theory that purports to capture what-it-is-like-ness, or alternatively as a modest theory of one kind of consciousness, or of consciousness in one sense of the term, higher order consciousness. The modest version of the higher order approach recognizes another kind of consciousness (or consciousness in another sense of the term), what-it-islike-ness or phenomenal consciousness. (Block 2011:421)

According to Block, the attempts made by ambitious HOT theorists to make sense of phenomenal consciousness face substantial, perhaps unsurmountable

\footnotetext{
${ }^{18}$ This appears to be Welshon's reading, according to which Nietzsche conceives of "basic" conscious states as both qualitative and representational (see 2014: 75; accessibility is a third feature Welshon attributes to states of this kind).
} 
difficulties. Arguably, an ambitious reading of Nietzsche's HOT account of $\mathrm{S}_{\text {consciousness would raise similar worries, for }} \mathrm{Q}_{\text {consciousness seems to be }}$ completely independent from the language-dependent, reflective capacities required for ${ }^{\mathrm{S}}$ consciousness. This means that to see Nietzsche as a modest theorist who allows that ${ }^{\mathrm{Q}}$ consciousness constitutes a kind different from and irreducible to ${ }^{S}$ consciousness would be to spare him from serious troubles. Thus, given how he construes ${ }^{\mathrm{S}}$ consciousness - consciousness in the dominant sense-, he has good reasons to endorse pluralism (or, at least, dualism).

One last question I would like to address is why Nietzsche is primarily concerned with ${ }^{\mathrm{S}}$ consciousness. This fact is particularly striking if one approaches the issue of consciousness from the angle of contemporary philosophy of mind. Here, most parts agree that the philosophically beefy notion is that of $\mathrm{Q}_{\text {consciousness. In the current idiom, }} \mathrm{Q}_{\text {consciousness is the "hard" problem for }}$ philosophers to deal with—so "hard", indeed, that some think it simply cannot be solved. So why does this notion play such a marginal role in Nietzsche's thought? In my view, part of the answer to this question has already been mentioned. The kind of "hard" problems raised by ${ }^{\mathrm{c}}$ consciousness are, mainly, of metaphysical and epistemological nature. These aren't the kind of problems on Nietzsche's own agenda. More interestingly, I believe that the problems we do find on his agenda also explain, on the positive side, his peculiar interest in ${ }^{\mathrm{S}}$ consciousness.

Nietzsche's main interest is in human agency. More precisely, he is interested in how human beings come to act in conformity to values and norms. Now, to be a moral agent requires one to be a self-conscious individual—one who can be made accountable for her own actions. Hence, Nietzsche pays particular 
attention to how self-consciousness has emerged and developed because it is part of how moral agency has emerged and developed.

There is, however, a way in which ${ }^{\mathrm{Q}}$ consciousness, too, is extremely relevant to Nietzsche's primary concern with agency. In the aforementioned note where he talks about qualities as being our "unclimbable barriers", he also says that they constitute "our human interpretations and values (Auslegungen und Werthe)" (N 1886 6[14], KSA 12:238). But what role exactly is ${ }^{\mathrm{Q}}$ consciousness supposed to play with respect to values?

Nietzsche maintains that the self is constituted by a specific set of drives whose hierarchic arrangement determines which values one endorses. ${ }^{19}$ Though Nietzsche's conception of the drives is highly debated, all interpreters tend to recognize that they are essentially affective. To put it differently, a drive cannot be individuated but by reference to a set of typical affective states which, as such, are intrinsically ${ }^{\mathrm{Q}}$ conscious states. For our discussion, the crucial point is that Nietzsche takes one's values to reflect the kind of affective, essentially ${ }^{Q_{\text {conscious }}}$ responses one typically displays. As he puts it in BGE 268, "[w]hat group of sensations (Empfindungen) in a soul will be the first to wake up, start speaking, giving order is decisive for the whole rank order of its values, and will ultimately determine its table of goods". Thus, it is in virtue of their fundamentally affective nature that drives determine which values we end up endorsing. This means, in turn, that for Nietzsche possession of an evaluative stance constitutively depends on sentience conceived as the capacity to undergo qualitative experience. As the course of one's agency is shaped by one's evaluative stance, there is thus a sense in which ${ }^{\mathrm{Q}}$ consciousness matters, after all, to the issues Nietzsche felt most 
appealed by. It is most probably thanks to its bearing in this way that this notion appears at all in his writings.

\section{References}

Nietzsche's works are cited by using the following abbreviations, followed by section title (if applicable) and section/aphorism number.

- D = Daybreak: Thoughts on the Prejudices of Morality. Trans. R. J.

Hollingdale. Cambridge: Cambridge University Press, 1997.

- GS = The Gay Science. Trans.

J. Nauckhoff, A. Del Caro. Cambridge: Cambridge University Press, 2001.

- BGE = Beyond Good and Evil: Prelude to a Philosophy of the Future. Trans. J. Norman. Cambridge: Cambridge University Press, 2002.

- TI = Twilight of the Idols. Trans. J. Norman, in F. Nietzsche: The Anti-Christ, Ecce Homo, Twilight of the Idols and Other Writings. Cambridge: Cambridge University Press, 2005.

- KSA = Kritische Studienausgabe in 15 Bände. Ed. G. Colli, M. Montinari. Berlin/New York: De Gruyter, 1980.

- Abel G. (2001): 'Bewußtsein—Sprache—Natur. Nietzsches Philosophie des Geistes'. Nietzsche-Studien 30: 1-43.

- Anderson L. R. (2002): ‘Sensualism and Unconscious Representations in Nietzsche's Account of Knowledge'. International Studies in Philosophy 34/3: 95-117. 
- Block N. (2011): 'The Higher Order Approach to Consciousness is Defunct'. Analysis 71/3: 419-31.

- Clark M. (1990): Nietzsche on Truth and Philosophy. Cambridge: Cambridge University Press.

- Constâncio J. (2011): ‘On Consciousness: Nietzsche’s Departure from Schopenhauer'. Nietzsche-Studien 40: 1-42.

- Constâncio J. (2012): 'Consciousness, Communication and Self-Expression. Towards an Interpretation of Aphorism 354 of Nietzsche's The Gay Science'. In J. Constâncio, M. J. Mayer Branco (eds.): As The Spider Spins. Essays on Nietzsche's Critique and Use of Language. Berlin, Boston: De Gruyter: 197232.

- Doyle T. (2011): 'Nietzsche, Consciousness and Human Agency'. Idealistic Studies 41: 11-30.

- Du Bois-Reymond E. (1882): ‘Über die Grenzen des Naturerkennens’. In: Über die Grenzen des Naturerkennens * Die Sieben Welträtsel. Zwei Vorträge. Leipzig: Verlag von Veit \& Comp.

- Jackson, F. (1982) 'Epiphenomenal Qualia'. The Philosophical Quarterly 32: $127-136$.

- Hatfield G. (2002): 'Perception as Unconscious Inference'. In D. Heyer and R. Mausfeld (eds.): Perception and the Physical World: Psychological and Philosophical Issue in Perception. Chichester: John Wiley \& Sons.

- Kant I. (1781/1787): Critique of Pure Reason. Ed. and trans. by P. Guyer \& A. W. Woods. Cambridge: Cambridge University Press 1998.

- Katsafanas P. (2005): 'Nietzsche's Theory of Mind. Consciousness and Conceptualization'. European Journal of Philosophy 13:1-31. 
- Katsafanas P. (forthcoming): 'Nietzsche on the Nature of the Unconscious'. Inquiry. Special Issue on Nietzsche's Moral Psychology, ed. by B. Leiter.

- Leibniz G. W. (1765): New Essays on Human Understanding. Transl. P. Remnant, J. Bennett. Cambridge University Press 1996.

- Liebmann O. (1880): Zur Analysis der Wirklichkeit. $2^{\text {nd }}$ ed. Strasbourg: Karl J. Trübner.

- Loukidelis N. (2006): 'Nachweis aus Otto Liebmann, Zur Analysis der Wirklichkeit'. Nietzsche-Studien 35: 302-3.

- Löwith K. (1967): Gott, Mensch und Welt in der Metaphysik von Descartes bis zu Nietzsche. Göttingen: Vandenhoeck \& Ruprecht.

- McDowell J. (1996): Mind and World. Cambridge (MA): Harvard University Press, $2^{\text {nd }}$ ed.

- Poellner P. (1995): Nietzsche and Metaphysics. Oxford: Clarendon Press.

- Reuter S. (2008): An der 'Begräbnissstätte der Anschauung'. Nietzsches Bild- und Wahrnehmungstheorie in 'Ueber Wahrheit und Lüge im aussermoralischen Sinne’. Basel: Schwabe.

- Riccardi (forthcoming): Nietzsche on the Superficiality of Consciousness.

- Riccardi (2015). Inner Opacity. Nietzsche on Introspection and Agency. Iquiry 58.3: 221-43.

- Riccardi (2013):'Nietzsche's Sensualism'. European Journal of Philosophy 21.2: $219-57$.

- Richardson J. (2004): Nietzsche's New Darwinism. Oxford, New York: Oxford University Press.

- Rosenthal D. (2005): Consciousness and Mind. Oxford: Clarendon Press. 
- Schlimgen E. (1999): Nietzsches Theorie des Bewußtseins. Berlin, New York. De Gruyter.

- Schopenhauer A. (1819-1844): The World as Will and Representation. Trans. by E. F. J. Payne. New York: Dover Publications, 1969, 2 vols. (=WWR)

- Simon, J. (1984): 'Das Problem des Bewußtsein bei Nietzsche und der traditionelle Bewußtseinsbegriff’. In. M. Djurič \& J. Simon (eds.), Zur Aktualität Nietzsches. Bd. II. Würzburg: Königshausen \& Neumann: 17-33.

- Welshon R. (2014): Nietzsche’s Dynamic Metapsychology. This Uncanny Animal. Basingstoke: Palgrave Macmillan. 